\title{
Features of the pathomorphological structure of the aterosclerotic plaques of carotid aterosclerosis
}

\author{
Yu. I. Kuzyk $k^{1,2}$ \\ ${ }^{1}$ Danylo Halytsky Lviv National Medical University, Ukraine, ${ }^{2} \mathrm{Cl}$ LRC “Lviv Regional Pathology Bureau”, Ukraine
}

A - research concept and design; B - collection and/or assembly of data; C - data analysis and interpretation; D - writing the article;

$\mathrm{E}$ - critical revision of the article; $\mathrm{F}$ - final approval of the article

Carotid arteriosclerosis is a recognized leader among causes of ischemic disorders of the cerebral circulation. It is known that brain infarction occurs with atherosclerotic stenosis and thrombosis of the carotid arteries in approximately $40 \%$ of cases. The peculiar geometry of carotid bifurcation creates conditions for the development of atherosclerotic plaques.

The aim of the work is determination of pathomorphological features of the structure of atherosclerotic plaques in carotid atherosclerosis.

Materials and methods. Histological, histochemical and immunohistochemical studies of surgical material in 680 patients were performed.

Results. On the basis of pathomorphological analysis of the plaque in carotid AS they can be divided into complicated and uncomplicated.

The first type is atheromatous unstable plaques with the prevalence of foci of atheromatosis, lympho-macrophage infiltration, intraplaque hemorrhage, necrosis of fibrous elements and edema. Immunohistochemically they are characterized by high expression of MMP-9 in macrophages and lymphocytes with degradation of type I collagen in the surface and deep layers of the plaque coating and its replacement by type III collagen $(P<0.05)$. The second type of plaque is stable uncomplicated with the advantage of fibrosis, hyalinosis and petrification. Immunohistochemical structure of plaques was collagen type I, expression of collagen type III was low, expression of MMP-9 was moderate $(P<0.05)$.

Conclusions. High expression of MMP-9 in carotid atherosclerosis in macrophage-lymphocytic infiltrates in atheromatosis and neovascularization sites was found to result in degradation of type I collagen with its replacement by type III collagen. Such pathomorphological changes underlie plaque instability - the development of intraplaque hemorrhages, ulcers with embolic complications. Synthesis of collagen type I with low expression of type III collagen and MMP-9 has been found to determine the basis of the structure of fibro-muscular plaques. This ensures their hemodynamic stability and stable vascular stenosis.

\section{Особливості патоморфологічної структури атероскиеротичних бляшок при каротидному атероскиерозі}

\section{Ю. І. Кузик}

Атеросклероз сонних артерій - визнаний лідер серед причин ішемічних порушень мозкового кровообігу. Відомо, що при атеросклеротичному стенозі та тромбозі сонних артерій приблизно в 40 \% випадків виникає інфаркт мозку. Особлива геометрія біфуркації сонних артерій створює умови для розвитку атеросклеротичних бляшок.

Мета роботи - визначення патоморфологічних особливостей структури атеросклеротичних бляшок при каротидному атеросклерозі.

Матеріали та методи. Здійснили гістологічне, гістохімічне та імуногістохімічне дослідження операційного матеріалу 680 хворих.

Результати. На підставі патоморфологічного аналізу структури бляшок при каротидному атеросклерозі розрізняли їх ускладнений і неускладнений типи. Перший тип - атероматозні нестабільні бляшки з перевагою вогнищ атероматозу, лімфомакрофагальної інфільтрації, внутрішньобляшкових крововиливів, некрозу волокнистих елементів і набряку. Імуногістохімічно для них характерна висока експресія ММП-9 у макрофрагах і лімфоцитах із деградацією організованого колагену I типу в поверхневих і глибоких шарах покришки бляшки та заміною його на колаген III типу $(p<0,05)$. Другий тип бляшок - стабільні неускладнені з перевагою фіброзу, гіалінозу та петрифікації. Імуногістохімічно структуру бляшок утворював колаген I типу, експресія колагену III типу низька, експресія ММП-9 помірна $(p<0,05)$.

Висновки. Висока експресія ММП-9 при каротидному атеросклерозі в макрофрагально-лімфоцитарних інфільтратах у вогнищах атероматозу та неоваскуляризації призводить до деградації колагену I типу з заміною його на колаген III типу. Такі патоморфологічні зміни становлять основу нестабільності бляшок, зумовлюючи розвиток внутрішньобляшкових крововиливів, виразкування з емболічними ускладненнями. Встановили, що синтез колагену I типу з низькою експресією колагену III типу та ММП-9 визначає основу фіброзно-м'язових бляшок. Це забезпечує їхню гемодинамічну стабільність і стійкий судинний стеноз.
Key words: MMP-9, type I collagen, type III collagen, type IV collagen, TIMP-1, atherosclerotic plaques, carotid atherosclerosis.

Pathologia 2019; 16 (3), 355-361 Dol: 10.14739/2310-1237. 2019.3.188872

*E-mail: juliakuzyk21@gmail.com

Киючові слова: ММП-9, колаген I, III, IV типу, ТІМП-1, атероскиеротичні бляшки, каротиАний атеросклероз.

Патологія. - 2019. T. 16, № 3(47). C. $355-361$ 
Киючевые слова: ММП-9, комлаген I, III, IV типа, ТИМП-1, атеросклеротические бляшки, каротиАный атеросклероз.

Патология. - 2019. T. 16, № 3(47). C. $355-361$

\section{Особенности патоморфологической структуры атероскиеротических бляшек при каротидном атероскиерозе}

\section{Ю. И. Кузык}

Атеросклероз сонных артерий - признанный лидер среди причин ишемических нарушений мозгового кровообращения. Известно, что при атеросклеротическом стенозе и тромбозе сонных артерий примерно в 40 \% случаев возникает инфаркт мозга. Особая геометрия бифуркации сонных артерий создает условия для развития атеросклеротических бляшек.

Цель работы - определение патоморфологических особенностей структуры атеросклеротических бляшек при каротидном атеросклерозе.

Материалы и методы. Проведено гистологическое, гистохимическое и иммуногистохимическое исследования операционного материала 680 больных.

Результаты. На основе патоморфологического анализа структуры бляшки при каротидном атеросклерозе выделили их осложненный и неосложненный типы. Первый тип - атероматозные нестабильные бляшки с превалированием очагов атероматоза, лимфомакрофагальной инфильтрации, внутрибляшечных кровоизлияний, некроза волокнистых элементов и отека. Иммуногистохимически для них характерна высокая экспрессия ММП-9 в макрофагах и лимфоцитах с деградацией организованного коллагена I типа в поверхностных и глубоких слоях покрышки бляшки и заменой его на коллаген III типа $(p<0,05)$. Второй тип бляшек - стабильные неосложненные с преобладанием фриброза, гиалиноза и петрификации. Иммуногистохимически структуру бляшек составлял коллаген I типа, экспрессия коллагена III типа низкая, экспрессия ММП-9 умеренная $(p<0,05)$.

Выводы. Высокая экспрессия ММП-9 при каротидном атеросклерозе в макрофрагально-лимфоцитарных инфильтратах в очагах атероматоза и неоваскуляризации приводит к деградации коллагена I типа с заменой его на коллаген III типа. Такие патоморфологические изменения лежат в основе нестабильности бляшек - развития внутрибляшковых кровоизлияний, язвы с эмболическими осложнениями. Установлено, что синтез коллагена I типа с низкой экспрессией коллагена III типа и ММП-9 определяет основу фиброзно-мышечных бляшек. Это обеспечивает их гемодинамическую стабильность и устойчивый сосудистый стеноз.

Carotid arteriosclerosis (AS) is a recognized leader among causes of ischemic disorders of the cerebral circulation. It is known that brain infarction occurs with atherosclerotic stenosis and thrombosis of the carotid arteries (CA) in approximately $40 \%$ of cases $[2,19,23]$. Given the high frequency and emphasizing the importance of atherosclerotic CA lesions in the development of cerebral disorders, some authors view it as a separate nosological unit, referring to the term "International Carotid Artery Disease" $[17,23]$. The authors dispute this because of the peculiarities of the geometric configuration of the CA bifurcation. Special geometric configurations in the arteries, such as bifurcations, bends, and anastomoses, can create focal areas of reduced tangential wall tension and promote smooth muscle cell proliferation. The concave surface of the convoluted arteries contributes to the reduction of the tangential stress of the wall, and in this place intimal thickening or atherosclerotic plaques (AP) develops. The most characteristic area of localized significant reduction of the tangent wall tension is carotid bifurcation. Atherosclerotic lesions of this localization account for $75 \%$ of all lesions of the extracranial arteries of the brain $[8,14,20]$. A number of researchers have studied the factors of AP progression, possibly predicting the development of instability and complications, including intracranial bleeding, thrombus progression, and inflammation $[1,2,7,10-12,19,21-23,25]$. Tan F. P. P. et al. [4] focuses on the distribution of hemodynamic forces, the appearance of turbulent flows in the stenosed artery in AS, which contributes to the growth of plaque size and the development of its instability. Makris G. C. et al. [18] proved that a change in the stress-deformed state of a vessel in AS, together with the redistribution of effective and tangential stresses, leads to plaque rupture due to the progression of intraplaque hemorrhages [5]. Therefore, the question of pathomorphological study of the structure of AP of CA is important for the establishment of possible features of plaques, prognosis and development of possible complications and correction of management of patients with carotid AS.

\section{The aim}

The aim of the work is determination of pathomorphological features of atherosclerotic plaques structure in carotid atherosclerosis.

\section{Materials and methods}

Altogether, over the 16-year period (2000-2015), surgical material of 680 patients operated at the Department of Vascular Surgery of Lviv Regional Clinical Hospital was analyzed and investigated. The operative material was 815 cases, as 135 patients underwent surgery on both CAs at different times. Surgical material, which was dependent on the type of surgery performed, was received in $10 \%$ neutral formalin solution. In each case, histological examination of the vascular wall preparations stained with hematoxylin eosin was performed. The sections were also stained with resorcinol-fuchsin by Hart, picrofuchsin by Weigert, Masson's trichrome. Immunohistochemical studies of CA biopsies were performed in paraffin sections using monoclonal and polyclonal antibodies. We used primary monoclonal antibodies to: collagen type I (Clone RAH C11-0,1 "Thermo Fisher Scientific Inc.", USA); collagen type III (Clone RAH C33 "Thermo Fisher Scientific Inc.", USA); type IV collagen (Clone CIV 22 "Thermo Fisher Scientific Inc.”, USA); matrix metalloproteinase-1 
inhibitor - Mo a-Hu TIMP-1 Ab-2 TIMP-1 (Clone 102D1, "Thermo Fisher Scientific Inc.", USA); polyclonal antibodies to matrix metalloproteinase- 9 - Rb aHu MMP-9 (92 kDa Collagenase IV, "Thermo Fisher Scientific Inc.", USA). Incubation with primary antibodies was performed according to the instructions of the manufacturers, visualization of the immunohistochemical reaction was performed using the DAKO EnVision + System (DAKO, USA) detection system with diaminobenzidine (DAB). The sections were stained with Mayer's hematoxylin and enclosed in Canada balsam. The expression intensity was evaluated by the semi-quantitative method as follows: "-" - negative immunohistochemical reaction; "+" - low intensity of expression; "++" is a moderate intensity of expression and "+++" is a clear intensity of expression.

A statistical survey of the data obtained was performed using the applications MS Excel 2003, Statistica 7 and IBM SPSS Statistics 19.

\section{Results}

Among the operated AS was identified in 286 (42.1\%) patients. The number of men was eight times higher than women (men 255, women 31). Patients' age ranged from 34 to 83 years. Most often, AS occurred in people aged $50-70$ years $-209(73.0 \%)$ patients. The predominant localization of the atherosclerotic process were both ICA - $156(54.5 \%)$ patients $(P<0.05)$. In second place in the lesion are both internal and external carotid arteries. AP practically in half of the cases captured the bifurcation of the external CA and moved to the initial departments of the internal CA. The first place in the frequency of lesions is the initial departments of internal CA - about $30 \%$. In the third place - up to $15 \%$ of AP were localized on the bifurcation of the external CA.

In the overwhelming majority ( $82 \%$ of patients), carotid endarterectomy - classic or eversion, and combinations of endarterectomy with other operations - resection, with redressing or reimplantation, were performed. With endarterectomy, plaque, intima, part of the media, and adventitia were removed according to protocols of operations of medical histories. The operating material included 327 biopsies, 162 of which were right carotid arteries, 165 left carotid arteries. Most of the biopsies - 153 (46.7 \%) had a conical shape and were represented by the inner parts of the sinus wall of the internal $C A$ with $A B, 110$ biopsies $(33.6 \%)$ by the inner parts of the bifurcation walls of the common CA and the initial sections of the internal and external carotid arteries with plaques in their walls. In each of the biopsies, a longitudinal surgical incision of the sinus wall of the CA was observed.

Pathomorphological examination revealed that most plaques had a complex structure due to the combination of various components both in circumference and in the depth of the bioptate. The revealed components of the plaque are characteristic for the severe form of AS: foci of atheromatosis, necrosis and edema, newly formed vessels, hemorrhages, inflammatory infiltration, sclerosis and calcinosis, thinning and ulceration of the plaque cap, parietal and obstructive thrombi $(P<0.05)$.

Sclerosis was a typical component of different types of AP. The degree of severity and prevalence of sclerotic changes in plaques varied: in $24(7.3 \%)$ biopsies fibrosis foci occupied practically the entire thickness of the slice, in $222(67.7 \%)$ plaques the fibrosis was focal and occupied the same area as atheromatosis, and calcinosis, in 77 $(23.4 \%)$ the fibrosis was insignificant $(P<0.05)$. Sclerosis was observed in the superficial layers of the plaque, in combination with hyalinosis formed a plaque. Stromal hyalinosis in half of cases was combined with vascular hyalinosis in the plaque.

Fibro-muscular plaques were observed in 26 (7.9\%) cases and consisted of a combination of diffuse fibrosis with proliferation of muscle fibers. Such plaques lacked lipid components. The muscle fibers were arranged in an orderly or chaotic fashion, with interlaced tufts forming. Fibro-muscular proliferation spread throughout the thickness of the vascular wall, occupying media and adventitia. In five cases, muscle plaques made of proliferating muscle fibers and smooth muscle cells (SMCs) were found.

Calcification was observed in $257(78.4 \%)$ cases. Significant foci of calcite were found in 127 AP (38.7 \%). They were located in atheromatous masses and occupied up to half of a piece of plaque. In 82 plaques ( $25 \%$ ), calcification foci destroyed vessel structures and penetrated deep layers of the medium, partly beyond the operating material.

Atheromatosis was observed in 231 (70.4\%) of complicated AP. The severity of atheromatosis varied quantitatively: in 51 biopsies, it occupied small areas in superficial or deeper layers of plaque. In half of the cases, atheromatosis was quite pronounced, reaching up to half of the plaque area and located in its deep layers. Atheromatosis was almost scattered in 28 cases, accounting for the bulk of the plaque. In such APs the destruction of atheromatous masses was completed by intraplaque tears and dissection with of large plaque fragments in the lumen of the ICA. In one third of cases of complicated plaques on the border with foci of atheromatosis areas of fibrinoid necrosis were detected, limited on the periphery by accumulations of macrophages and proliferating fibroblasts. The deposition of cholesterol crystals in the foci of atheromatosis was observed in $62.5 \%$ of cases. At the destruction of the cap atheromatous masses with cholesterol crystals penetrated into the lumen of the ICA.

Cellular infiltration in plaques was observed in 240 $(73.1 \%)$ cases. Foamy macrophages were the most common cells in the infiltrate, forming significant foci or small-focal infiltrates. Macrophages were localized on the border with foci of atheromatosis and fibrous elements in the superficial and deep layers of plaques. In 134 (40.8\%) biopsies, a large number of foamy macrophages were observed; in $82(25.0 \%)$ there were moderate clusters. In half of AP lymphocytes were detected. In a third of the plaques, they were observed near the new vessels, among macrophage infiltrates, both in the superficial and deep layers of the plaques. Lymphocytes in AP were defined as clusters of single cells - $90(27.4 \%)$, in 63 $(19.2 \%)$ - in the form of focal clusters $(P<0.05)$. Near atheromatous masses, in particular near the cholesterol crystals, numerous or single giant cells were observed in $13(3.9 \%)$ cases.

A high level of MMP-9 expression was observed in the cell infiltrate at the foci of atheromatosis. Intensive 

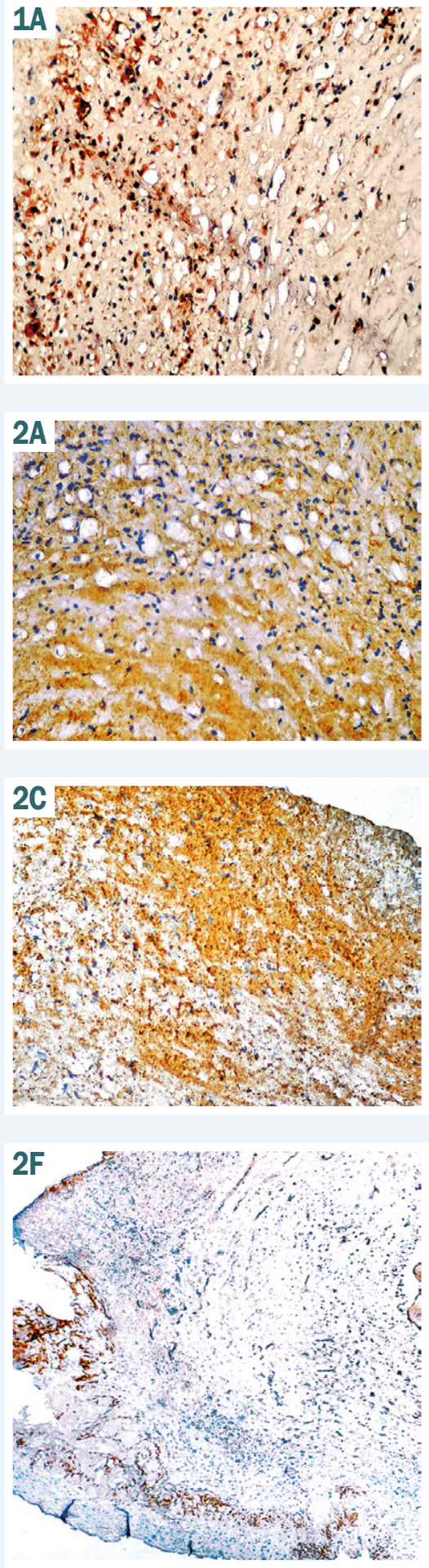
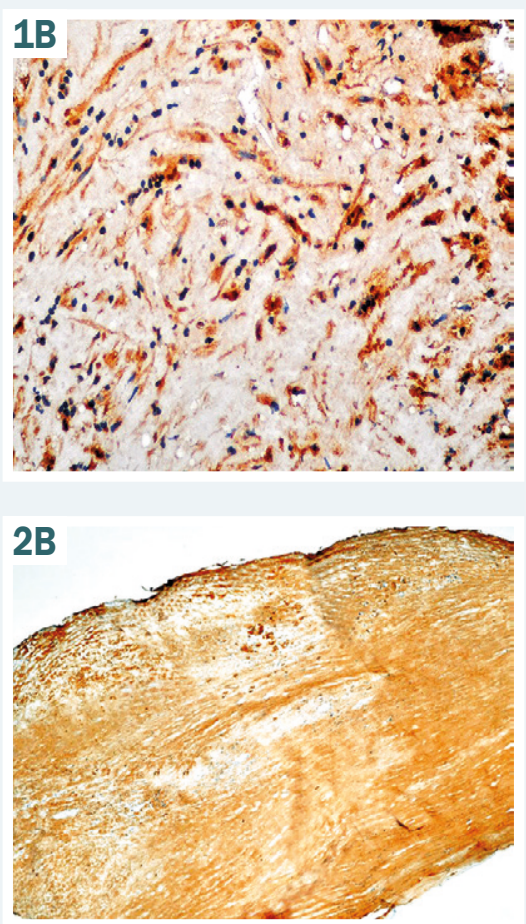

Fig. 2. The expression of I, III and IV types of collagen in carotid AS:

expression of type I collagen: A: in atheromatous plaques, B: in fibro-muscular plaques;

expression of type III collagen: C, D: in atheromatous plaques, E: in fibro- fibro-muscular plaques:

expression of IV types of collagen: $\mathrm{F}$ : in atheromatous plaques, G: in fibro-muscular plaques plaques.

Clone RAH C11-0,1; Clone RAH C33, Clone CIV 22 visualization system DAKO EnVision + System with DAB.

Magnification: A, B, E ×100, C, D ×200, F, G ×40.
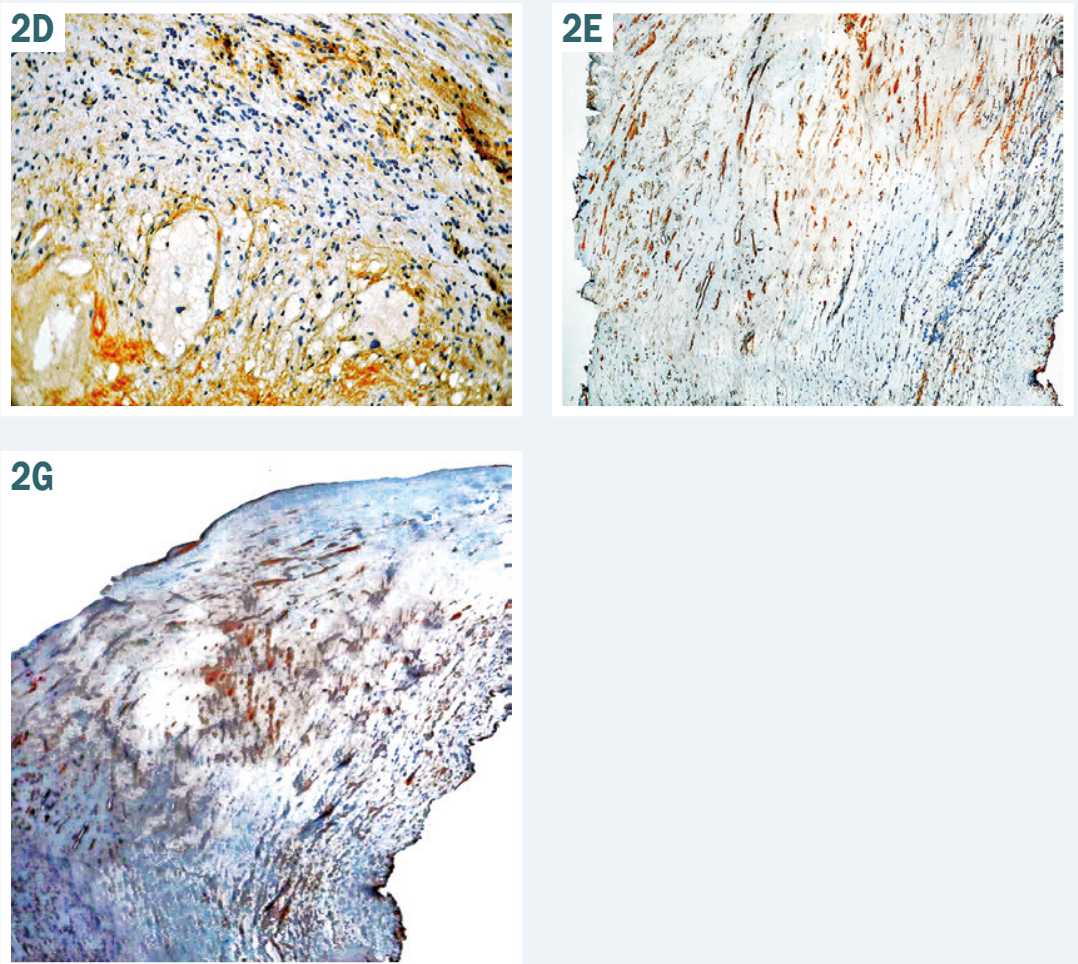

granular cytoplasmic expression was determined in macrophages and lymphocytes (Fig. 1). The activity of MMP-9 in the studied plaques was parallel to the increase in inflammatory cell infiltration $(P<0.05)$. In areas of cellular infiltration with high expression of MMP-9, the expression of TIMP-1 was negative.

Newly formed vessels in plaques were detected in $94(28.6 \%)$ cases of operating material. According to the peculiarities of the structure, we have three types of vessels - sinusoidal, capillary and closed types. Sinusoidal vessels of different diameters were prevalent in the superficial layer, some of them localized in the marginal layers of the plaques, that is, on the border with the preserved or slightly altered inner ICA layer. Most of these vessels are located along the length of the vessel and are sometimes connected to the vascular lumen. In a third of cases, capillary-type vessels were observed among thin-walled sinusoidal vessels. They were located 
in groups immediately adjacent to the intraplaque hematoma and foci of hemosiderosis. The third type of vessels in the areas of neovascularization had the structure of closed arteries with thick, relative to their lumen, walls due to the proliferation of SMCs and elastic fibers. Nine cases of closed-type vessels revealed signs of fibrinoid necrosis with pronounced swelling of adjacent tissues, and $12(3.6 \%)$ of AP had sclerosis with lumen obliteration. Groups of capillaries and sinuses were adjacent to the individual closed arteries. A significant number of thin-walled vessels were found in $20(6.1 \%)$ plaques, a moderate number in $28(11.7 \%)$, and single (60 $(18.3 \%)$ ) vessels; the closed arteries in all plaques were single. In $52(15.8 \%)$ AP, there was a close location of closed type arteries and thin-walled vessels, suggesting the formation of arterio-venular anastomoses in plaques. Neovascularization in the plaque had a direct correlation with intraplaque hemorrhage $(r=0.89 ; P<0.05)$.

Intraplaque hemorrhage was observed in $118(36 \%)$ cases. The hemorrhage foci were of different sizes and spread: small - in 45 (13.7\%) plaques and large - in 73 (22.2\%). Small foci of hemorrhage were localized mainly in the deep layers of AP and didn't disturb its integrity, although they led to an increase in its volume and progression of stenosis. Great focal hemorrhages in 70 (21.3\%) cases were complicated by plaque dissection - multiple or single internal ruptures with a significant dissection hematoma were observed, which in 63 (19.2\%) cases resulted in partial or complete detachment of plaque fragments. Intramural hematomas with plaque dissection and detachment of its fragments formed multiple dissection zones. This led to the development of a multi-storey dissection with involvement of surface and deep layers of the plaque in the process.

The plaque caps consisted of a variety of muscle and connective tissue fibers, often with hyalinosis, which limited foci of atheromatosis or calcification from the lumen of the ICA. Fibroblasts, foamy macrophages and lymphocytes were often identified in fibers in various amounts and ratios. In 93 plaques $(28.3 \%)$, the cap was thinned and calcined, with 15 (4.5\%) defective plaque cap, where calcification foci penetrated its surface. In areas of atheromatosis in $22(6.2 \%)$ plaques, the cap was thinned and consisted of connective tissue. In 83 $(25.3 \%)$ cases, atheromatosis revealed ulcerations and destruction of the cap. The sections of the ulcer varied in length and depth. The largest ulcers were determined in $12(3.6 \%)$ cases and had a length of up to $25 \mathrm{~mm}$ with destruction of more than $1 / 3$ of the cap. In 35 (10.6\%) plaque ulcerations were found in the area of thinning with foci of atheromatosis. In $35(14.7 \%)$ cases, the plaques cap was peeled off and partially detached as a result of intraplaque hemorrhage.

Fresh and organized thrombi were detected on the surface of $85(25.9 \%)$ AP. Parietal thrombi were observed in $38(16 \%)$ cases in the areas of thinning and ulceration of the cap with atheromatous masses, in six cases they were located on the unchanged surface of the plaques. Obstructive thrombi were detected in 41 cases $(17.2 \%)$. Of these, signs of organization were observed in 12 (3.6\%), in two cases the thrombi were organized. Obstructive thrombus in 20 cases occurred in the areas of ulceration and thinning of the plaque surface, in other cases - on a sclerosing surface.

Analysis of the expression of types I, III and IV collagen in carotid AS showed the following (Fig. 2).

In complicated atheromatous plaques, collagen type I expression is moderate and predominates in deep AP layers. Immunopositive collagen deposits were located in or near inflammatory infiltrations - between the clumps of foam cells and lymphocytes. Expression of type III collagen in atheromatous plaques is intense and heterogeneous. Immunopositive type III collagen deposits prevailed in the surface layers of AP beyond the foci of atheromatosis and inflammatory infiltration. In the deep layers within the foci of atheromatosis and inflammatory infiltrate the expression of collagen type III is moderate and in some places weakly expressed. In fibro-muscular plaques, collagen type I expression is a clear, almost diffuse, spread. Immunopositive collagen type I deposits are spread along the entire length of the plaque. Type III collagen expression is weak in all plaque layers $(P>0.05)$. The expression of type IV collagen in the plaques of both atheromatous and fibro-muscular muscles was not significantly different $(r=0.45 ; P>0.05)$. It is weakly expressed, heterogeneous, predominates in the deep layers of the plaque on the border with the unchanged layers of the vascular wall.

\section{Discussion}

The pathomorphological study allowed us to distinguish two types of AP among the operating material. The first type is complicated atheromatous unstable plaques with the predominance of atheromatosis foci, lympho-macrophage infiltration, intraplaque hemorrhage, necrosis of fibrous elements and edema. Immunohistochemically, they are characterized by high expression of MMP-9 in macrophages and lymphocytes with degradation of type I collagen in the superficial and deep layers of the plaque coating and its replacement by type III collagen. It is known that AP macrophages produce a significant number of MMPs that are involved in collagen degradation $[6,13]$. Proteases initiate the process of destruction of the structure of the atheromatous plaque, increasing the likelihood of its separation from the vascular wall and the appearance of emboli, the development of intraplaque hemorrhage $[11,18,19]$. Increased level of MMP-9 leads to the formation of type III collagen from SMCs in the form of thin and less organized fibers. Replacement of organized collagen type I by type III collagen leads to a decrease in the mechanical stability of the fibrous capsule in AP $[15,16,24]$.

The second type of plaque is fibro-muscular $A B$, stable uncomplicated with the advantage of fibrosis, hyalinosis and petrification. The immunohistochemical structure of such plaques was collagen type I, the expression of collagen type III was low; the expression of MMP-9 was moderate. The expression of type IV collagen in plaques of both atheromatous and fibro-muscle is not significantly different. It is weakly expressed, heterogeneous, predominates in the deep layers of the plaque on the border with the unchanged layers of the vascular wall. It is believed that a decrease in type III collagen 
content and an increase in type I and IV collagen leads to increased vessel rigidity, increased brittleness, and a tendency to rupture $[15,16]$.

In order to study the features of the structure of AP in carotid AS, we conducted a study of the major components and processes that determine plaque morphology. In AP of CA structural changes characteristic of severe AS were pathomorphologically revealed: foci of atheromatosis, petrification, edema, necrosis of fibrous elements, newly formed vessels and hemorrhages of varying degrees of prescription, macrophage-lymphocytic infiltration, foci of fibrosis and hyalinosis, parietal and obstructive clots. Most researchers have studied the features of ulcerative plaques as "unstable". An equivalent complication of AP according to our data is intraplaque hemorrhage. The latter are described by other authors as the cause of the sudden sharp increase in the volume of AP and the development of massive ischemic stroke $[19,22]$. In addition, an increase in plaque volume and, consequently, a decrease in vascular lumen, intraplaque hemorrhage threaten with dissection with impaired plaque integrity and fragments detachment $[21,23]$. It should be noted that the sizes of detached fragments in intraplaque hemorrhage significantly exceed the size of the embologenic atheromatous masses during ulceration of plaques $[2,10,12,23]$. This leads to the development of massive high-fatality strokes. This massive embolization was due to the fact that the hemorrhages are localized in the deep layers of the plaque, the stratified intraplaque hematoma causes a detachment of more than $1 / 2$ the volume of the plaque. The pathogenesis of plaque hemorrhage remains to be fully elucidated $[1,3,9]$. In our opinion, closed-type vessels are formed due to the fact that blood enters the vessels of the plaque from the high-pressure area of the ICA, and thus the arterio-venular anastomoses perform a bypass function. In the case of insufficient function of the closed vessels, the high intra-arterial pressure can be transmitted directly to the thin-walled vessels of the plaque-the source of hemorrhage. The basis for this assumption is the detection of clusters of siderophages around such vessels. This mechanism of intraplaque hemorrhage can be realized with fluctuations in systemic blood pressure, especially when it is raised. Thus, Z. Teng et al. [12,22] also believe that high blood pressure leads to mechanical trauma of the plaque with next rupture of small vessels due to changes in stressstrain state and stress fluctuations. It should be noted that intraplaque hemorrhages among our material acted as components of multicomponent plaques and were combined with foci of atheromatosis, cholesterosis, calcification and lympho-macrophage inflammation. Therefore, another possible mechanism for the development of intraplaque hemorrhage may be laceration in the area of atheromatous plaque due to a sharp rise in blood pressure, followed by rupture of newly formed vessels and the development of local dissection hematoma. Q. J.van den Bouwhuijsen et al. [11], after conducting a series of AP studies, tend to believe that hemorrhages can occur even in asymptomatic plaques, which in addition to newly formed vessels contain significant foci of calcification and atheromatosis. This suggests that the development of intraplaque hemorrhage is related to the plaque structure and the distribution of hemodynamic forces.

\section{Conclusions}

1. On the basis of pathomorphological analysis of the plaque in carotid AS they can be divided into complicated and uncomplicated. The first type is atheromatous unstable plaques with the prevalence of foci of atheromatosis, lympho-macrophage infiltration, intraplaque hemorrhage, necrosis of fibrous elements and edema. Immunohistochemically, they are characterized by high expression of MMP-9 in macrophages and lymphocytes with degradation of type I collagen in the surface and deep layers of the plaque coating and its replacement by type III collagen $(P<0.05)$. The second type of plaque is stable uncomplicated with the advantage of fibrosis, hyalinosis and petrification. Immunohistochemical structure of plaques was collagen type I, expression of collagen type III was low, expression of MMP-9 was moderate $(P<0.05)$.

2. High expression of MMP-9 in carotid atherosclerosis in macrophage-lymphocytic infiltrates in atheromatosis and neovascularization sites was found to result in degradation of type I collagen with its replacement by type III collagen. Such pathomorphological changes underlie plaque instability - the development of intraplaque hemorrhages, ulcers with embolic complications. Synthesis of collagen type I with low expression of type III collagen and MMP-9 has been found to determine the basis of the structure of fibro-muscular plaques. This ensures their hemodynamic stability and stable vascular stenosis.

Prospects of further research are to carry out a comparative analysis of ultrasonic and pathomorphological structure of carotid plaques with determination of diagnostic difficulties and causes of mismatch of morphological and ultrasonic structure.

Conflicts of interest: author has no conflict of interest to declare. Конфлікт інтересів: віАсутній.

Надійшла Ао редакції / Received: 23.08.2019

Після Аоопрацювання / Revised: 16.09.2019

Прийнято Ао Аруку / Accepted: 07.10.2019

Information about author:

Kuzyk Yu. I., MD, PhD, DSc, acting Professor of the Department of Pathological Anatomy and Forensic Medicine of Danylo Halytsky Lviv National Medical University, Pathologist of the CI LRC "Lviv Regional Pathology Bureau", Ukraine.

Відомості про автора:

Кузик Ю. І., А-р меА. наук, в. о. професора каф. патологічної анатомії та судової медицини, Аьвівський національний медичний університет імені Аанила Галицького, лікарпатологоанатом КЗ ^ОР "^ьвівське обласне патологоанатомічне бюро", Україна.

Сведения об авторе:

Кузык Ю. И., А-р меА. наук, и. о. профессора

каф. патологической анатомии и судебной меАицины, ^ьвовский национальный медицинский институт имени Аанила Галицкого, врач-патологоанатом КЗ ^ОР "^ьвовское областное патологоанатомическое бюро", Украина.

\section{References}

[1] Anufriev, P. L., Gulevskaya, T. S., \& Evdokimenko, A. N. (2013). "Nestabil'naya" struktura ateroskleroticheskikh blashek karotidnogo sinusa i narusheniya mozgovogo krovoobrashcheniya ["Unstable" structure 
of carotid sinus atherosclerotic plagues and disturbances of cerebral blood circulation]. Sovremennye problemy nauki i obrazovaniya, 3 , 1-8. [in Russian]. Retrieved from http://www.science-education.ru/ru/ article/view?id=9288

[2] Anufriev, P. L., Evdokimenko, A. N., \& Gulevskaya, T. S. (2018). Infarkty golovnogo mozga pri ateroskleroze arterii vertebrobaziliarnol sistemy [Cerebral infarctions in vertebrobasilar artery atherosclerosis]. Arkhiv patologii, 80(1), 3-10. [in Russian]. https://doi.org/10.17116/ patol20188013-10

[3] Hetterich, H., Webber, N., Willner, M., Herzen, J., Birnbacher, L., Hipp, A., ... Saam, T. (2016). AHA classification of coronary and carotid atherosclerotic plaques by grating-based phase-contrast computed tomography. European Radiology, 26(9), 3223-3233. https://doi. org/10.1007/s00330-015-4143-z

[4] Tan, F. P. P., Soloperto, G., Bashford, S., Wood, N. B., Thom, S., Hughes, A., \& Xu, X. Y. (2008). Analysis of Flow Disturbance in a Stenosed Carotid Artery Bifurcation Using Two-Equation Transitional and Turbulence Models. Journal of Biomechanical Engineering-Transactions of the Asme, 130(6). https://doi.org/10.1115/1.2978992

[5] Birchall, D., Zaman, A., Hacker, J., Davies, G., \& Mendelow, D. (2006). Analysis of haemodynamic disturbance in the atherosclerotic carotid artery using computational fluid dynamics. European Radiology, 16(5), 1074-1083. https://doi.org/10.1007/s00330-005-0048-6

[6] Tan, C. H., Liu, Y., Li, W. N., Deng, F., Liu, X., Wang, X., . . Chen, L. F. (2014). Associations of matrix metalloproteinase-9 and monocyte chemoattractant protein-1 concentrations with carotid atherosclerosis, based on measurements of plaque and intima-media thickness. Atherosclerosis, 232(1), 199-203. https://doi.org/10.1016/j.atherosclerosis. 2013.11 .040

[7] Silvestre-Roig, C., de Winther, M. P., Weber, C., Daemen, M. J., Lutgens, E., \& Soehnlein, O. (2014). Atherosclerotic Plaque Destabilization Mechanisms, Models, and Therapeutic Strategies. Circulation Research, 114(1), 214-226. https://doi.org/10.1161/circresaha.114.302355

[8] Bijari, P. B., Wasserman, B. A., \& Steinman, D. A. (2014). Carotid Bifurcation Geometry Is an Independent Predictor of Early Wall Thickening at the Carotid Bulb. Stroke, 45(2), 473-478. https://doi.org/10.1161/ strokeaha.113.003454

[9] Flaherty, M. L., Kissela, B., Khoury, J. C., Alwell, K., Moomaw, C. J., Woo, D., . . Kleindorfer, D. (2013). Carotid Artery Stenosis as a Cause of Stroke. Neuroepidemiology, 40(1), 36-41. https://doi. org/10.1159/000341410

[10] Gupta, A., Baradaran, H., Schweitzer, A. D., Kamel, H., Pandya, A., Delgado, D., ... Sanelli, P. C. (2013). Carotid Plaque MRI and Stroke Risk A Systematic Review and Meta-analysis. Stroke, 44(11), 30713077. https://doi.org/10.1161/strokeaha.113.002551

[11] Van den Bouwhuijsen, Q. J. A., Bos, D., Ikram, M. A., Hofman, A Krestin, G. P., Franco, O. H., . . . Vernooij, M. W. (2015). Coexistence of Calcification, Intraplaque Hemorrhage and Lipid Core within the Asymptomatic Atherosclerotic Carotid Plaque: The Rotterdam Study. Cerebrovascular Diseases, 39(5-6), 319-324. https://doi. org/10.1159/000381138

[12] Teng, Z. Z., He, J., Degnan, A. J., Chen, S. Y., Sadat, U., Bahaei, N. S. .. Gillard, J. H. (2012). Critical mechanical conditions around neovessels in carotid atherosclerotic plaque may promote intraplaque hemorrhage. Atherosclerosis, 223(2), 321-326. https://doi.org/10.1016/j. atherosclerosis.2012.06.015

[13] Jager, N. A., Vries, B. M. W., Hillebrands, J. L., Harlaar, N. J., Tio, R. A., Slart, R.,... Westra, J. (2016). Distribution of Matrix Metalloproteinases in Human Atherosclerotic Carotid Plaques and Their Production by Smooth Muscle Cells and Macrophage Subsets. Molecular Imaging and Biology, 18(2), 283-291. https://doi.org/10.1007/s11307-015-0882-0

[14] Uslu, B., Cakmak, Y. O., Sehirli, U., Keskinoz, E. N., Cosgun, E., Arbak, S., \& Yalin, A. (2016). Early Onset of Atherosclerosis of The Carotid Bifurcation in Newborn Cadavers. Journal of Clinical and Diagnostic Research, 10(5), AC1-AC5. https://doi.org/10.7860/jcdr/2016/19827.7706

[15] Fields, G. B. (2013). Interstitial Collagen Catabolism. Journal of Biological Chemistry, 288(13), 8785-8793. https://doi.org/10.1074/ jbc.R113.451211

[16] Libby, P. (2013). Collagenases and cracks in the plaque. Journal of Clinical Investigation, 123(8), 3201-3203. https://doi.org/10.1172/jci67526

[17] Lim, S. N., Chang, Y. J., \& Lin, S. K. (2016). Extracranial Carotid Artery Disease Risk Factors and Outcomes in Patients With Acute Critical Hemispheric Ischemic Stroke. Journal of Ultrasound in Medicine, 35(2), 341-348. https://doi.org/10.7863/ultra.15.03070

[18] Makris, G. C., Nicolaides, A. N., Xu, X. Y., \& Geroulakos, G. (2010). Introduction to the biomechanics of carotid plaque pathogenesis and rupture: review of the clinical evidence. British Journal of Radiology, 83(993), 729-735. https://doi.org/10.1259/bjr/49957752

[19] Bentzon, J. F., Otsuka, F., Virmani, R., \& Falk, E. (2014). Mechanisms of Plaque Formation and Rupture. Circulation Research, 114(12), 18521866. https://doi.org/10.1161/circresaha.114.302721
[20] Huang, X Yin, X P Xu, Y J. Jia, X W Li, J. H Niu, P ... Huo, Y. L. (2016). Morphometric and hemodynamic analysis of atherosclerotic progression in human carotid artery bifurcations. American Journal of Physiology-Heart and Circulatory Physiology, 310(5), H639-H647. https://doi.org/10.1152/ajpheart.00464.2015

[21] Michel, J. B., Martin-Ventura, J. L., Nicoletti, A., \& Ho-Tin-Noe, B. (2014) Pathology of human plaque vulnerability: Mechanisms and consequences of intraplaque haemorrhages. Atherosclerosis, 234(2), 311-319. https://doi.org/10.1016/j.atherosclerosis.2014.03.020

[22] Teng, Z. Z., Sadat, U., Brown, A. J., \& Gillard, J. H. (2014). Plaque hemorrhage in carotid artery disease: Pathogenesis, clinical and biomechanical considerations. Journal of Biomechanics, 47(4), 847-858. https://doi.org/10.1016/j.jbiomech.2014.01.013

[23] Altaf, N., Kandiyil, N., Hosseini, A., Mehta, R., MacSweeney, S., \& Auer, D. (2014). Risk Factors Associated With Cerebrovascular Recurrence in Symptomatic Carotid Disease: A Comparative Study of Carotid Plaque Morphology, Microemboli Assessment and the European Carotid Surgery Trial Risk Model. Journal of the American Heart Association, 3(3). https://doi.org/10.1161/jaha.113.000173

[24] Van Doren, S. R. (2015). Matrix metalloproteinase interactions with collagen and elastin. Matrix Biology, 44-46, 224-231. https://doi. org/10.1016/j.matbio.2015.01.005

[25] De Wilde, D., Trachet, B., Van Der Donckt, C., Vandeghinste, B., Descamps, B., Vanhove, C., ... Segers, P. (2015). Vulnerable plaque detection and quantification with gold particle-enhanced computed tomography in atherosclerotic mouse models. Molecular Imaging 14(4). https://doi.org/10.2310/7290.2015.00009 